\title{
Muslims Responses to Pandemics: Lessons from the Best Generation
}

\author{
Che Mohamad $C A^{1}$, Shahar $M A^{2}$, Md Tahir MF', Syed Abd. Hamid SAK \\ ${ }^{1}$ Kulliyyah of Pharmacy, International Islamic University Malaysia, Kuantan Campus, Bandar Indera Mahkota, \\ Kuantan, Pahang. \\ ${ }^{2}$ AVISENA Specialist Hospital, No. 4, Jalan Ikhtisas, Seksyen 14, 40000 Shah Alam, Selangor \\ ${ }^{3}$ Kulliyyah of Medicine, International Islamic University Malaysia, Kuantan Campus, Bandar Indera Mahkota, \\ Kuantan, Pahang.
}

\section{ABSTRACT}

The world is currently suffering from another episode of respiratory disease pandemic as Coronavirus Disease 2019 (COVID-19) spares no continent. The disease which is caused by the virus SARS-CoV-2, has so far claimed many lives in multiple countries, including Muslim majority nations like Malaysia and Saudi Arabia. The situation has become a significant public health concern with several measures being carried out in an attempt to break the chain of the virus transmission. These include the introduction of movement control order and total lock down across the world. The closure of places of worship including mosques have raised concerns and inconvenience to Muslims. Pandemics are not unprecedented in the history of mankind as several documented outbreaks like the plague pandemic in the mid fourteenth century also known as 'the Black Death', caused a demographic decline in both Muslim and Christian countries which led to millions of lives loss worldwide. We attempt to identify the parallels between the current COVID-19 pandemic with the experiences of previous Muslim generations, and draw lessons on general and practical responses to pandemics with special reference to the generation of the Prophet's companion.

KEYWORDS: Muslims; Pandemics; Coronavirus; COVID-19; Plague

\section{INTRODUCTION}

The world is currently suffering from another episode of respiratory disease pandemic. Following the emergence of the 2019 novel coronavirus (SARS-CoV-2) infection in Wuhan, December 2019, it rapidly spread across China and several other countries. ${ }^{1}$ The disease is officially known as Coronavirus Disease 2019 (COVID-19) and has claimed many lives in various countries, including Muslim nations like Malaysia and Saudi Arabia.

The situation has become a significant public health concern with several measures being carried out in an attempt to break the chain of the virus

Corresponding Author:

Asst. Prof. Dr. Che Anuar Che Mohamad Kulliyyah of Pharmacy, International Islamic University Malaysia, Kuantan Campus, Bandar Indera Mahkota, 25200, Kuantan, Pahang

Tel No : +609-5704882

Email : dranuar@iium transmission. These include the introduction of movement control order and total lock down with the international borders being closed. In response to this pandemic, Malaysia has ordered the closure of all mosques and other places of worship, prohibiting mass gathering, as part of the movement control order (MCO).

Pandemics are not unprecedented in the history of mankind. There have been several documented pandemics, among those was the plague pandemic in the mid fourteenth century, also known as 'the Black Death' which led to a demographic decline in both the Muslim and Christian countries. ${ }^{2,3}$ While pandemics are primarily medical problems, history has shown that the responses were influenced by religion, belief systems as well as cultural values. ${ }^{3}$

The current COVID-19 pandemic has produced a remarkable impact on the nature of ritual worship in Islam, including those regarded as major and compulsory under usual circumstances. Social 
distancing, which is one of the measures taken has directly affected congregational worship and funeral arrangements as to prevent the virus transmission.

This is not the first time Muslims had to shift from their usual ritual of worship. As a holistic belief system, Islam accommodates physical, emotional, and spiritual well-being at both individual and societal levels; not merely concerned with the issues of maintaining the religious duties during difficult times. Instead, Islam comes with various preventives measures through guidance on etiquette which may prevent or mitigate the disease transmission. The prophetic tradition indicates Islam's prohibition on coughing and sneezing without proper etiquette.

Based on the general guidelines of Islamic teachings, we attempt to identify the parallels between the COVID-19 pandemic with the experiences of the previous Muslim generation and draw lessons on general and practical responses to pandemics; with special reference to the generation of the Prophet's companion RA.

\section{Diseases and pandemics in the Quran}

There are some examples in the Quran indirectly relating to disease outbreaks. Generally there are no specific words that could be attributed to a disease, unlike the way "at-ta'un" was mentioned in the prophetic traditions. However, the stories mentioned reflect upon a problem affecting a nation which is suggestive to the occurrence of a disease outbreak.

The following verse highlights the signs granted to Moses (pbuh) as a punishment for the disbelievers of Egypt i.e. Pharaoh and his people.

"So We sent upon them the flood and locusts and lice and frogs and blood as distinct signs, but they were arrogant and were criminal people". (7:133)

They were afflicted with a series of plagues. It affected the entire nation severely forcing them to plead to Moses (pbuh) to pray for the punishment to be removed by God. ${ }^{5}$

Another verse narrates the story of the dead people who escaped the plague in their land. ${ }^{6}$

"Have you not considered those who left their homes in many thousands, fearing death? Allah said to them, "Die"; then He restored them to life. And Allah is full of bounty to the people, but most of the people do not show gratitude." (2: 243)

This was referring to four thousand people from Banu Israel who ran away from their villages which were affected by plague. However, they died as a result of the angels' scream when they arrived at a fertile valley, despite their attempt to escape death from the epidemic. ${ }^{6}$

\section{Disease and pandemics in hadith and historical treatises}

In comparison to the Quran, epidemics were explicitly stated in the hadith literature. ${ }^{3}$ These hadith collections related to plague epidemics have been the references to plague treatises written by Muslim writers after the Black Death and became the source for reconstruction of a fairly uniform chronology of plague epidemics in early Islamic history. ${ }^{3}$ The discussions on plague and epidemics in hadith would channel the reader into the parallels of the previous history of plague and other pandemics with the current pandemic of COVID-19.

One should understand the intended meaning of two important terminologies i.e. ta'un and waba' in the text of hadith to benefit more from the hadith in this matter. Al-Nawawī in his commentary of the hadith related to plague, described ta'un as gangrenous pustules with darkening (necrosis) and painful swelling in the axillae which is suggestive of bubonic plague. ${ }^{7,8}$ Al-Nawawi description on ta'un seemed to be in agreement with the meaning of ta'un in another hadith which was compared to the ghuddah of a camel i.e a deadly disease characterized by swollen lymph glands. ${ }^{7}$

Waba' refers to a general epidemic of certain diseases and according Al-Nawawi, involves a state of illness affecting much of the population of one specific region as opposed to other regions. ${ }^{7,8}$

Al-Nawawi shared with Ibn Sina, the description of ta'un which was suggestive of bubonic plague. Therefore, it appears certain that the ta'un of the Arabic sources, including the hadith literatures, is suggestive of a bubonic plague based on the documented descriptions on the symptoms and severity. This is further supported by the growing 
consensus in the international scholarly community which identifies the Black Death as a plague pandemic caused by a bacteria known as Yersinia pestis. ${ }^{9,10}$

Both hadith literature and historical account indicated that the first disease outbreak or epidemic faced by the earlier Muslim community was the Plague of Amwas which occurred seven years following the death of Prophet Muhammad SAW. ${ }^{8,10}$ Earlier on, a relatively smaller epidemic in Syria occurred at the time of Umar RA. He was informed by Abu Ubayda regarding the plague as he was about to enter the city. Umar then decided to return to Madinah after consulting his other companions from Ansar, Muhajirin and former leaders of the Qurasy. It was after the decision was made based on his ijitihad then Abdul Rahman bin Auf came in to relate from Prophet Muhammad SAW:

"If you hear of an outbreak of plague in a land, do not enter it; but if the plague breaks out in a place while you are in it, do not leave that place. "Sahih Bukhari. 8,10,11

The above narration has laid important foundations on how Muslims should deal with plagues, referring to a disease which has already spread in certain areas. One of the foundations which was accepted as a general rule is for Muslims to avoid entering a plague-stricken city but should not try to flee if they are already there. ${ }^{8,11}$

Pertaining to this, classical Muslim scholars have formulated three religio-legal principles, namely: (1) plague is a mercy from God and a martyrdom for the faithful Muslim; (2) a Muslim should not enter nor flee from a plague-stricken land; and (3) there was no contagion of plague since disease came directly from God. These three principles regarding plague were inherited by Muslim scholars at the time and have been the basis in influencing the Muslim communal behaviour in facing disease epidemics although not all Muslim scholars were in agreement. 2,3

Umar's decision has led to a long debate on the right response to plagues and other diseases. Abu 'Ubayda argued that the cancellation of the mission was like running away from God's decree. However, Umar's decision which was also supported by prophetic tradition that was narrated by Abd Rahman bin Auf on the same occasion, has become the general rule adopted by later Muslim authors on plague and epidemic i.e. one should avoid entering a plaguestricken city, but should not try to flee from it if he was already there. ${ }^{3}$ Despite differences in opinions, they i.e. Umar RA and other companions during his time, had collectively tried their best to prevent the disease transmission while accepting it as the decree of Allah.

Another fundamental issue was on the contagious nature of the disease. Muslim scholars reconciled between the two conflicting concepts with the following conclusion; even though contagion existed, it was with God's permission that a person would become ill. Most works on the subject however, argued for either the existence or nonexistence of contagion and consequently whether one should or should not flee a plague-stricken area. The third ijtihaad (on non-contagious nature of the disease) was refuted by scholars such as Ibnu Sina. Ibnu Sina argued the contagious nature of tuberculosis which precisely corresponded to current medical knowledge.

Even though the contagious nature of the disease was not widely accepted by the early Muslim community, there were few physicians who believed in the contagion theory. Amongst them was Ibn al-Khatib, who recognized that outbreaks of plague coincided with the arrival of contaminated men, whilst the isolated communities remained uncontaminated. His observation on the effect of pneumonic plague further supported the belief of the interhuman transmission of the disease rather than attributed to miasma. ${ }^{16}$ Ibn al-Khatib recommended people to stay away from the sick which is in line with the current concept of quarantine. ${ }^{2,3,7}$

In later occasion, the plague pandemic had caused mosques to be either closed or emptied in Qayrawan $(395 \mathrm{H})$. Similarly, many mosques were closed in Egypt during the Black Death. However, the closure was assumed to be due to the high mortality and related impact of the diseases. Nevertheless, it could have been closed as a preventive measure to curb the spread of the disease, considering the medical advances during both periods. ${ }^{15}$ 
Islamic positions and responses in facing the pandemics

Muslims view any form of affliction including disease pandemic, as a test from Allah that promises great rewards to those who face them with patience and submission. Muslims acknowledge that the ongoing disease pandemic is from Allah as mentioned in the holy Quran:

"Who has created death and life that He may test you which of you is best in deed." (67:2)

This verse reminds us that Allah who had created life and death; and whatever is in it from the afflictions, in order to test which one of us is better in deed than others. For a believer, the acknowledgment of God's total control over everything in this world turns them to God for assistance and solace. ${ }^{5}$ Muslims are therefore reminded in the following verse in the face of any calamity:

"Who, when disaster strikes them, say, 'Indeed we belong to Alläh, and indeed to Him we will return." (2:156)

As Muslims believe that life and death are determined by the will of God, similarly the current COVID-19 pandemic should be regarded as an integral part of God's order of things. Muslims accept the suffering or even death as a form of test. Instead of complaining, he chooses to sincerely seek Allah's forgiveness and turns to Allah in all of his affairs as the calamity could also serve as a warning from Allah for wrongdoings as highlighted in following verses:

"And whatever of misfortune befalls you, it is because of what your hands have earned. And He pardons much." (42:30)

Previous Muslim generations have been exemplary in formulating their plan of action in their effort to overcome the epidemic despite some 'misapprehension' related to the understanding on the contagious nature of the disease. ${ }^{13}$ As a leader, Umar RA has approached the plague during his time with caution and wisdom where he arranged a meeting with companions from Ansar and Muhajirin, as well as those among the leaders of Quraysh in trying to figure out the potential solution in facing the epidemic in Syria in $18 \mathrm{H} / 639$ AD. ${ }^{3,8}$ Umar RA decided to return to Medina as this was the opinion of majority which was also supported by the leaders of the tribe of Quraish who were older, more experienced in life and had sustained more life trials making their judgement more logical and acceptable. ${ }^{8}$ He demonstrated on how to handle similar cases of outbreak i.e. through meetings and consultations with people of knowledge and wisdom. Despite his virtues and positions which were divinely recognized, he did not out of arrogance, resort to making a decision by himself on the matter. The decision not to enter the epidemic area was otherwise preferred based on 1) tawakkal and acceptance to Allah's decree and 2) element of careful and cautious approach as well as prevention of harmful outcome. ${ }^{3}$

The Caliph Umar's RA measures reflected a balance approached and has set an important precedent for the following Muslims generations. He had indicated that the disease epidemic was a clear mafsadah which needed to be prevented through any permissible means. His balanced approach had set an example for other leaders to follow scientifically to the latest medical advancement when managing pandemics.

The Ottomans empire provided us many lessons with regards to the plague. Medicine was becoming more professionalized in the Ottoman Empire by the 16th century. The new generation of physicians began to practice evidence-based medicine using empirical evidence in treating the plague. They began to distinguish between the Black Death and other diseases that were also included under the term for plague. It resulted in greater emphasis on hygiene as stressed in the teachings of Prophet Muhammad SAW. ${ }^{2,18}$

Muslims should maintain good thoughts about Allah and spread positivity in times of calamity. Despite the trial, Muslims should always be looking forward to His blessings and forgiveness.

\section{"None of you should die without having good expectations in Allah". (Muslim)}

What matters to Muslims in times of hardship is how to deal with the test from God. With the correct attitude and action, the ultimate outcome is to gain blessings and forgiveness from The Almighty. Allah 
mentioned in the Quran,

"And We divided them throughout the earth into nations. Of them some were righteous, and of them some were otherwise. And We tested them with good [times] and bad that perhaps they would return [to obedience]." (7: 168)

Indeed, at times man regain the consciousness of reality when faced with hardship like the current COVID-19 pandemic. Some, even begin to seek for God in order to be peaceful at heart as he is aware of the escalating mortality of COVID-19. In another verse, Allah says:

"Those who have believed and whose hearts are assured by the remembrance of Allah. Unquestionably, by the remembrance of Allah hearts are assured." (13: 28)

The following verse puts emphasis on our own response instead of judging others during times of calamities.

"That was a nation which has passed on. It will have [the consequence of] what it earned, and you will have what you have earned. And you will not be asked about what they used to do." (2:134)

And for all the effort that a believer puts in to deal with the test from Allah, He has promised a meaningful end. This is one of the basis for Muslims to always remain hopeful as recorded in the Quran,

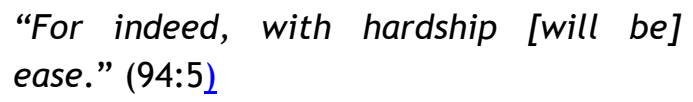

In Islam, life is held in the highest esteem and the duty to preserve life forms one of the core principles in Maqasid al Shari'ah. In a disease outbreak situation where many lives are at stake, saving as many lives as we can is something that the Quran advocates through the following ayat.

"Because of that, We decreed upon the Children of Israel that whoever kills a soul unless for a soul or for corruption [done] in the land - it is as if he had slain mankind entirely. And whoever saves one-it is as if he had saved mankind entirely...." (5:32)

Apart from the important role of the frontliners among them the healthcare workers, everyone needs to be aware of the devastating impact from the single index case once it spreads. It is therefore critical for every individual to play their part to limit the disease transmission during this pandemic.

In the event of an outbreak, authorities are required to take drastic actions; sometimes at the expense of other factors - such as economy or politics - in order to save lives. As pandemic threatens public health security, every Muslim has to comply to the advice from the experts. The success of curbing the transmission of a disease during pandemic largely depends on the adherence compliance to policies at both national and international levels. This is when a highly self-motivated and well-informed population is far more effective in implementing decisions by leaders than a policed and ignorant population.

\section{CONCLUSION}

From theological perspective, we should first response with repentance and selfless charity instead of despair and regret. It would be simplistic to approach the current COVID-19 pandemic merely as a medical issue whilst ignoring the divine messages. This pandemic challenge the global nation to find the potential treatment, however other challenges remain to be further identified and reflected. Muslims in particular, should regard the current pandemic as a test from God Al-Mighty, a call to return to Him; believe in His Wisdom for such a trial and remain hopeful for a recovery.

We have learnt from Muslim history that Islamic teachings guide us on how an individual and the community have dealt with a disease outbreak. Many lessons were drawn from their experiences in facing the pandemics, however these do not translate to all that were done in the past by Muslim were sacred. However, their experiences have at least provided us with some perspectives on how Muslims value life and react in the most dignified manner amidst the pandemic chaos. Current policies on managing pandemics, including prevention of transmission, actions taken by authorities and fellow citizens are generally in-line with the teachings of Islam. 


\section{REFERENCES}

1. Lai CC, Shih TP, Ko WC, Tang et al. Severe acute respiratory syndrome coronavirus 2 (SARS-CoV-2) and corona virus disease-2019 (COVID-19): the epidemic and the challenges. International journal of antimicrobial agents 2020;105924.

2. Dols MW. The comparative communal responses to the Black Death in Muslim and Christian societies. Viator 1974, 5:269-288.

3. Dols MW. Plague in Early Islamic History. Journal of the American Oriental Society 1974;94(3), 371 -383 .

4. Kamali MH. Principles of Islamic jurisprudence. The Islamic Text Society; 1991.

5. Qutb S, Salahi MA, Shamis AA. In the Shade of the Quran. Islamic Foundation, 2002

6. Ibn Kathir I. Tafsîr ibn kathîr. Riyadh: Dar-usSalam, 2000.

7. Conrad L. Tāaūn and Wabāa Conceptions of Plague and Pestilence in Early Islam. Journal of the Economic and Social History of the Orient 1982; 25(3), 268-307

8. Al-Nawawi Y, Muslim SS. Cairo: $1^{\text {st }}$ edition, Dar Alfawaid, 2008

9. Hanbal I. Ahmad, al-Musnad. Damascus, Dar Al Fikr, vl, 1993.

10. Ayalon $Y$, The Black Death and the Rise of the Ottomans. In Natural Disasters in the Ottoman Empire: Plague, Famine, and Other Misfortunes. Cambridge University Press, 2014

11. Al-Asqalani, I. H. Fathul Bari Sharh Sahih al Bukhari. Riyadh: Dar Salam, 2000.

12. Al-Asqalani, I.H. Badzlul Ma'un fi Fadhli Tha'un. Riyadh: Dar al-Ashimah.

13. Dols MW. The Second Plague Pandemic and Its Recurrences in the Middle East: 1347-1894. Journal of the Economic and Social History of the Orient 1979: 22(2), 162-189.

14. Varlik N. New Science and Old Sources: Why The Ottoman Experience of Plague Matters. In Green M. (Ed.), Pandemic Disease in the Medieval World: Rethinking the Black Death. Kalamazoo; Bradford: Arc Humanities Press, 2015:193-228.

15. Latif A. We've Been Here Before: Plague and Pestilence in Pre-Modern Islamic History. Available at https: //yaqeeninstitute.org. Accessed April 19, 2020.

16. Dols MW. The Black Death in the Middle East. Princeton: Princeton University Press. muse.jhu.edu/book, 2019.
17. Khaldun I. The Muqaddimah, English Edition Transl. Franz Rosenthal. 1967

18. Legan, Joseph A, "The medical response to the Black Death" (2015). Senior Honors Projects, 2010-current. 103. Available at https: / /commons.lib.jmu.edu / honors201019/103

19. Obaidullah M. Medical Science and Islam: An analysis of the Contributions of the Medieval Muslim Scholars.

20. Varlik N. From "Bête Noire" to "le Mal de Constantinople": Plagues, Medicine, and the Early Modern Ottoman State. Journal of World History 2013: 24(4), 741-770.

21. Varlik N. Plague and contagion in the Islamic Mediterranean. ISD LLC; 2017 Apr 30.

22. Wang C, Horby PW, Hayden FG, Gao GF. A novel coronavirus outbreak of global health concern. The Lancet 2020: 395(10223), 470 $-473$.

23. World Health Organization. (2020). Coronavirus disease 2019 (COVID-19): situation report, 67.

24. Wu Z, McGoogan JM. Characteristics of and Important Lessons from the Coronavirus Disease 2019 (COVID-19) Outbreak in China: Summary of a Report of $72 \square 314$ Cases From the Chinese Center for Disease Control and Prevention. JAMA.

25. Yuval Noah Harari. The world after coronavirus. Available at https:// amp.ft.com / content/19d90308-6858-11eaa3c9-1fe6fedcca75 Accessed April 2, 2020. 